\title{
ONTOLOGICAL PRINCIPLES OF ANCIENT PHILOSOPHY AS A METHODOLOGICAL CHALLENGE
}

\section{Vozniak S. V.}

\section{INTRODUCTION}

Ancient philosophy - the beginning of philosophy in general, both in historical and content-thematic sense. The modern philosophy behind this statement is paradoxically contradictory: on the one hand, the actual influence of ancient philosophy is not in dispute; moreover, there is evidence of a growing interest in the ancient philosophical heritage both in academia and in amateur circles. But on the other hand, attraction of modern philosophy toward reduction to a discrete set imperatively oriented to practical utility, "topical" relevance so as unified formalized intellectual practices - "technologies" a priori reduces the interest in ancient philosophy to the abstract statement of its universal significance. In modern methodological practices of reading ancient philosophy there is a fundamental lack of contextual and meaningful immersion in the essential dimensions of philosophical thinking represented by ancient tradition. This failure is this: despite numerous and quite effective recourse to ancient texts as the foundation of modern logic, ethical and epistemological research question of the ontological meaning and origins of ancient philosophy boils down to the assertion of a number of favorable and / or the necessary prerequisites and reasons of different order. In our opinion, this floor' solved with the specific historical and contemporary philosophical methodology in which there is a fundamental, sometimes even declarative rejection of attempts to grip the history of philosophy as a single, strategically directed and internally consistent metanarrative; such a seizure seems to gravitate towards a totalitarian way of thinking in which local, self-worthy, and self-contained philosophical landscapes are reduced and leveled. But with the rejection of "totalitarian pressure" and "sub" objectively permissiveness penetrating interpretation of the history of philosophy, which often abandoned Hegel, Marx and Heidegger, we refuse and the ability to understand antiquity in its ontological, fundamental principles. In this case, our reference to the historical and philosophical landscapes destined to work exclusively with local texts, ideas and problems without the possibility of establishing semantic called connection between thinking and historical form of ontological sources of thinking itself. In the context of the topic of this study, it is worded as follows: alienation of the beginnings of philosophy is alienation of philosophy in general. 
In spite of the chronological and, in places, the supposedly meaningful "timelessness", it is necessary to mention the fundamental works of G. Hegel, M. Heidegger, and A.F. Losev as the most systematically and comprehensively embracing and problematizing ancient philosophy, revealing its semantic correlation with the subsequent historical and philosophical process. In frames of the appeals to the ancient tradition of a historical and philosophical formation in modern European and American philosophy should be named monographic work Q. Ado, John Reale and D. Antiseri, F. Koplston (tradition, conventionally designated as «continental»), and - regular texts and monographs $\mathrm{J}$ Annas, M. Byurneyat, M. Fred M. Canto-Sperber, John Barnes, L. Brison, J. Brunschwig and G. Vlastos and many others (English and American philosophy, analytical philosophy). It is striking that if European texts tend to comprehensively define ancient philosophy as an element of the history of philosophy, the tradition of English and American philosophy mainly focuses on the local paradigms and trends of antiquity; most often it is Aristotle's philosophy, Stoicism and skepticism. Among the Russian texts, the works of V. Bibikhin, N. Motroshilova, P. Haydenko, D. Dorofeiev, R. Svetlov, I. Mochalova, and Y. Davidov should be noted. Special attention deserves Authors M. Wolf, P. Butakov and I. Berestov and since published them in Ukrainian journal Sententiae article is devoted to analysis of project history of ancient philosophy, of direct interest to our study.

Domestic studies of ancient philosophy are characterized by locality in the appeal to individual ideas and representatives (again, the most common analyst of Aristotelianism and Hellenistic philosophy) and propedeutic in the creation of a systematic tradition of studying ancient philosophy (mostly text). It should be noted the following authors: A. Ahutin, A. Baumeyster, V. Petrushenko, A. Panich, M. Popovich, S. Ploleyev, T. Lyuty, A. Khoma.

The purpose of the study is to analyze methodological possibilities of entering into the question of the principles of ancient philosophy.

\section{Review of existing methodological approaches}

Let's start with a clearer outline of the question we have formulated about the beginnings of ancient philosophy. In this case it is not a matter of stating the reasons and prerequisites for the birth of the latter. Beginnings are both a chronological beginning and, at the same time, the primary ontological foundation from which our own philosophical thinking begins. A thorough knowledge of the geographical, climatic, cultural, social, formation, worldview prerequisites that contributed to the emergence of ancient philosophy in no way gives us a vision of what a shift occurs in the vision and way of understanding the world at this "zero moment", to what philosophical thought no, and after which, here it is. 
Rather, it is important here to formulate the initial inquiry correctly. From what vision of the world and ourselves in it feeling the need to consider things not empirically, not through the prism of mythological interpretation, but - look at things their internal untrackability at empirical pointing ("here it is") interconnection' main roads, build it pre-reflexive, intuitive feeling of connection not to mythological or religious revelations, but - to some intellectually contemplated source, which presents unity in relation to set things in the world? This question is not a question of motivation or historical result, it is a question of a way of discovering and finding a person in the world and the world precisely as an internally unified "world". General thesis of cosmocentric and materialistic worldview as one of the most powerful sources of formation of philosophy ("ancient culture - is not only about objectivism, it is also sensitive material cosmologism. In this it differs from medieval philosophy and religion absolute spirit" ) is meaningful and productive for understanding the specifics of ancient thinking, but it still leaves us in a descriptive statement, since the "worldview as cosmos", which is invisibly present in the event of ancient culture, is inaccessible to modern research practices in its ness and relevance optics and angle of view.

Why is it unattainable? Because modernity is distant from the event of ancient philosophy, distant and chronological, meaningful and problematic. "What are we to Parmenides? What is Parmenides to us?"2. Of course, it should be noted here that this distance is a necessary distance in order to cover the subject holistically, to see the boundary contours of ancient philosophy, while approaching the subject, we better see its quality color, details and nuances, while losing the sense of contour. But our vision and understanding of philosophy proceeds from a fundamentally different worldview and worldview: the scientific character of our worldview first forms a theoretical «frame» within which the theoretical results are implemented into the practice of existence - from experimental application to life - practical solutions, whereas for the given the choice of life position and daily practice precedes the formation of theoretical systems. This difference demonstrates brilliantly P. Ado in his work "What is Ancient Philosophy?", Stating the following: "Theoretical philosophical discourse is thus born from this initial existential option, and it leads back to it, insofar as - by means of its logical and persuasive force, and the action it tries to except upon the interlocutor - it

${ }^{1}$ Лосев А. Ф. Дерзание духа. М., Издательство политической литературы, 1989. 366 с. C. 154-155.

2 Петрушенко В. Л. Иов или о человеческом самостоянии. Львов, ПП «Новий світ2000», 2008. 339 c. C. 161. 
incites both masters and disciples to live in genuine conformity with their initial choice" "3. (It should be noted here that P. Ado's research demonstrates a typical for "continental" philosophy of focusing on a sense of the general, delineating and organizing contour of the subject). However, the question of the existential basis of existential choice should be raised here, since it is a qualitative basis for the question of the beginnings of ancient philosophy.

Nevertheless, despite the obvious distance and ideological difference, ancient philosophy is still thought of as something akin to contemporary philosophical practices - even when the question of the ontological beginnings of ancient philosophy is brought to our attention. The nature of this affinity is thought differently, and here it is necessary to distinguish and summarize the most common ways of presenting ancient philosophy in the present.

Expansion and development of modern theories and systems of logic that occur both foreign (primarily American and British analytical projects) and in the national philosophy, spread the influence of analytical traditions of the Russian and Ukrainian intellectual space inevitably bring back to life a closer attention to the logic of Aristotle, conceived as a unique twist: “... refine initial concepts analytical philosophy based on modern symbolic logic brings us to the ideas of Aristotle, forgotten or separated from today with Millenniums. The effect of rediscovering forgotten truths is well known to me in the history of science, but the logic of Aristotle since its inception has never been in the shadow of recent advances in scientific knowledge, it belongs to both antiquity, the Middle Ages, and the most recent times"4. In those words, M. Popovich opens a roundtable on the 2400th anniversary of Aristotle's birth. Also, a number of recent articles published in Philosophical Thought testify quite thoroughly to the problems of logic and philosophy from the standpoint of Aristotelianism. Thus, V. Navrotsky notes that "Taking into account the peculiarities of practical considerations, having clarified the role of the concept of acceptance in the analysis of such considerations and the question of the applicability of dialectical models for the analysis of simplistic reasoning, we conclude that there are convincing signs of a practical turn in modern logical community right up to Aristotle",

${ }^{3}$ Hadot P. What is ancient philosophy? Cambridge, Mass.: Belknap Press of Harvard University Press, 2002. P. 3.

${ }^{4}$ Аристотель і аристотелізм: 2400 років по тому. Круглий стіл «Філософської думки». Ахутін А., Баумейстер А., Білий О., Васильченко А., Гомілко О., Жулай В., Звіядковський В., Козловський В., Попович М., Пролеєв С., Терлецький В., Туренко В., Хома О. Філософська думка : Наук. вісн. 2016. № 5. С. 6-26. URL: http://journal.philosophy.ua/ issue/2016-no5. C. 6.

5 Навроцький В. «Топіка» Аристотеля і практичний поворот у сучасній логіці. Філософська думка: Наук. вісн. 2016. № 5. C. 27-32. URL: http://journal.philosophy.ua/ issue/2016-no5. C. 32. 
Within the framework of the reception of Aristotle's philosophy, the problem of translating the terminology into the Ukrainian language, related to the sometimes unsolvable complexities, is actualized in national thought:

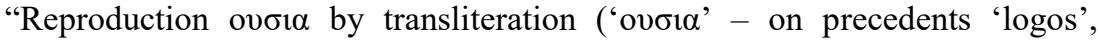
'category', 'agora') is the least traumatic for translating and commenting on Aristotle left texts into Ukrainia",

In addition to setting the theoretical called' communication essential aspects of ancient philosophy to modern philosophical issues in the national mind there are still attempts to comprehensively describe continuous relationship with the ancient philosophy parameters thinking and human existence in general. Here is an exemplary statement of A. Baumeister: "Are people interested in ancient philosophy today? To me, this is the same as asking, 'Does a person have a request to be a man?' "7. Also pay attention to the works of Ahutin: "Europe - a forum of the world", which in a very condensed form shows historical connection and integrity of European culture as a historical event that is not conceived without philosophy which begins in ancient thought: "There is no European 'rationalism' at all, and there is a philosophy that asks what it means to think, to understand, to know: what is the truth of the true, how does the 'pure mind' understand, how possible (as intended) thinking thought, which is primordial, more primordial than it a priori arhitectonics?" ${ }^{\circ}$. We can already hear the echo of the same question that is the purpose of our research: how to think the beginning of thinking? Where to find the ontological little principle early European philosophy?

For our study, it is important to mention at least a partial indication of the problematization of ancient philosophy in the American-analytical tradition. Here, too, there is a locality and instrumentality fixed by us, when we carefully study individual teachings, thoughts and paradigms of thinking in relation to the present or in their authentic existence within the historical tradition, but there is practically no attention to the question of the beginnings of ancient thought. However, it is a characteristic feature of analytic philosophy that by its very definition avoids formulation and immersion within metaphysical questions: "What we cannot speak about we must pass over in silence" .

\footnotetext{
${ }^{6}$ Панич О. Аристотелева «усія»: між субстанцією, сутністю і неперекладністю. Філософська думка: Наук. вісн. 2016. № 5. C. 33-49. URL: http://journal.philosophy.ua/issue/ 2016-no5. C. 49.

7 Стан і перспективи українського антикознавства. Круглий стіл «Філософської думки». Баумейстер А., Вестель Ю., Звонська Л., Панич О., Пролеєв С., Чорноморець Ю., Секундант С. Філософська думка: Наук. вісн. 2012. № 1. C. 5-25. URL: http://journal.philosophy.ua/issue/2012-no51. C. 7.

${ }^{8}$ Ахутин А. В. Европа - форум мира. К., Дух і літера, 2015. 88 с. С. 6.

${ }^{9}$ Ludwig Wittgenstein. Tractatus Logico-Philosophicus. Pt. 7. URL: http://writing.upenn.edu/ library/Wittgenstein-Tractatus.pdf
} 
This demonstration is of $\mathrm{J}$. Annas, who still do not have a translation words' Slavic languages in which the author actualizes some aspects of ancient philosophy in the context of their non-representation in traditional antiquity or lack of work with the terms towards compliance with current theories. Thus, in her work Hellenistic Philosophy of Mind, she states the following: "Why was Hellenistic philosophy of mind held to be crude? The main reason is that all major theories are physicalist; they hold that the mind is (with refinements we will examine) something physical. And until surprisingly recently the philosophical background of scholars interpreting Hellenistic philosophy was one in which the dominant theory was dualism. From here we often find scholars dismissing Hellenistic theories as being in principle on the grounds that they merely study the material conditions for mental activity to be possible"10. We see that the study of ancient philosophy within the tradition of American philosophy inevitably encounters the virtually insurmountable difference between the original positions of the latter with antiquity; no historical relation is at stake here. Awareness of the need to overcome this unrelatedness is a phenomenon of the last decades.

In the context of this phenomenon, the issue of creating an adequate methodological approach to ancient philosophy is actualized. Here, too, there is an attempt to distance oneself from the "continental", classical tradition of interpreting antiquity as the basis of the cross-cutting history of philosophy. In the monograph M. Canto-Sperber, J. Barnes, L. Brison, J. Brunswig, G. Vlastos "Greek Philosophy" read the following: "The style of our Greek philosophy is mainly a style of analysis and reflection. It is characterized by the refusal to paraphrase the concepts of the authors being studied, and at the same time the desire to describe the corpus of their works, to analyze the problems they are discussing and to understand their arguments. Each work is tasked with showing what questions the studied philosopher has interpreted, what methods of argumentation and conceptual means he has used, and what they provide for a common understanding of the philosophical problem. The authors of this paper do not share the idea that there is a single form of progress - from thinkers of the pre-Platonic period to philosophers of the Christian era. The studies included in this book acknowledge the importance of the influence of each philosopher on posterity; at the same time, each concept is considered in itself, regardless of the apparent global philosophical progress" $"$.

${ }^{10}$ Annas Julia E. Hellenistic Philosophy of Mind. Berkeley : University of California Press, 1992. 246 р. Р. 2.

${ }^{11}$ Греческая философия, Том 1. Антология. М. Канто-Спербер, Дж. Барнс, Л. Бриссон, Ж. Брюнсвиг, Г. Властос. Пер. с англ. М., 2006, «Греко-латинский кабинет» Ю. А. Шичалина. 520 с. С. 2. 
Disclaimer philosophical ideas of continuity creates the need to establish such a methodology, which would be automatically overcome all the contextual bar' premieres on the way to the authenticity of ancient thought, presenting it in non-signed, direct light self-sufficiency and self-worth. And this is where the frontal omission of the fundamental question of the marginal dimensions of ancient philosophy and its ontological beginnings is recorded.

Thus, in the Ukrainian edition of the Sententiae in 2013 a group of authors M. Wolf, P. Butakov and I. Berestov and published an article which offers project analysis the history of ancient philosophy. Again, the text contains a rather serious critique of the "previous" ways of interpreting the history of philosophy as a cross-cutting, continuous way of unfolding thought. The project is characterized as follows: "In terms of our approach, first, we approach the analysis of the text with a claim to objectivity and lack of engagement, unless we set ourselves the urge to enroll the thinker in any historical process, but to give he is rated as a 'typical representative' of a particular tradition. Secondly, we are not interested in the metaphysical picture of the world, the doctrine of God, or the moral principles described in the text under study, but the author's methods of substantiating statements, ways of constructing a theoretical model, and the depth of argumentation. In this regard, our project has little in common with the aforementioned [historical and teleological - S.V.] directions of continental humanities"12. That is essential under this approach is not "that" philosophical problems, and "how" of its embodiment. Certainly, this is a fundamentally important component of philosophy, because it enables thinking to trace ways of its implementation at the level of reflection, logic, self- transparency and selfreporting. As part of the analysis of the "how", the authors propose to formalize the argumentation of ancient thinkers in the language of modern logic: "Philosophical tools and methods developed by analytical philosophers of the twentieth century. Are indispensable for solving our problems. This methodology includes both ways of formalizing arguments, and attention to syntax and logical semantics, and just a certain increased demand for clarity of language and argument. Ultimately, the analytical historical and philosophical approach is not just about writing formulas, it is rather a style or ambition based on the presumption of our ability to express the argument contained in the ancient text, as well as the presumption of rationality of the author of the text, even if the text itself deals with religious issues"13.

12 Вольф М., Бутаков П., Берестов И. Аналитическая история античной философии. Sententiae: Наук. вісн. 2013, № 1 (XXVIII). С. 96-108.

${ }^{13}$ Вольф М., Бутаков П., Берестов И. Аналитическая история античной философии. Sententiae: Наук. вісн. 2013, № 1 (XXVIII). С. 96-108. 
In general, this approach, of course, brings us closer to a clearer understanding of the ways in which ancient thought is unfolded, but it does not in any way contradict the philosophical traditions that have been called "continental" by the authors. We see that in the current tendency of criticizing those philosophical positions and paradigms that tend to depict the history of philosophy as a particular metanarrative, there is a completely unjustified refusal to recognize such positions as a right and an opportunity to work with local landscapes at the level of careful identification of their uniqueness and self-worth. Critics are mainly concerned with trying to comprehend the history of philosophy from borrowing and dialectics, usually Hegelian or Marxist; in domestic philosophy, there is also a rather sad and wholly nonphilosophical rhetoric regarding dialectics as a totalitarian method of implementation of communist ideology, characterized exclusively by the totalitarian era of the Soviet Union. In such optics, any attempt to immerse oneself in the basic, ontological parameters of the relation of thinking and being in the historical and philosophical perspective is thought of as somewhat totalitarian and toxic to the local author / idea / text / system. Instead, we propose totalitarian methodological and narrative pluralism as an end in itself for philosophical thinking - in our view, this leads to the total disappearance of the possibilities of philosophical dialogue (however, it is obvious that this thesis requires a separate deployment).

\section{Problematic formation of historical and philosophical methodology}

Any attempt to formulate the method of out-of-context, direct, and unfounded entry into the fabric of a particular historical and philosophical landscape outlined above is doomed to failure, since any formalization is a formalization within one or another tradition (context, point of view, position in the world and stories...). The movement to extra-contextualism and "purity" in explicating forms of thinking takes place in a much more complex way and of course, in the history of philosophy the attempts to «brace» the historical, psychological, cultural, social "mediators" of thought occupy a very important place. However, there is a fundamental ontological context that attempts to "nullify", "format" these data, since it is the position from which we abstract and formalize this or that context - it is always the position of our being-in-the-world, the position of the primary, pre-reflexive, pretheoretical "abandonment", "orientation" in the world. That is why the question of going to a particular transcendental position with respect to the boundary contours of thinking as such is such an "irresistible" problem - by asking the question of boundary contours, we do not go beyond them, as if we did not attempt to formalize thinking. There is no distance that would create the necessary optics of our view of thinking. 
This is why this distance is so important in historical and philosophical research. It is through her that the ontological, fundamental principles of our thinking receive the necessary specificity. In fact, when we ask about the beginnings of ancient philosophy (in the sense of "who sought to find ancient thinkers, beginning to think the very thinking?"), We ask about the beginning of thinking in general. V. Bibikhin's statement is relevant here: “...Thought $<\ldots>$ can not be anything other than the first philosophy. This means that it must be able to start over ..."14. Each of our philosophies, regardless of historical time and function, is a search for a starting point for thinking, and therefore it is always "for the first time".

Thus, the omission in view of the question of the ontological beginnings of ancient philosophy, or the provision of a formal answer to this question, is reminiscent of the omission fixed by M. Heidegger of being as such. Stating the question of being as empty and the most general concept, we do not express anything essential about being - on the contrary, rather, we are preparing the ground for its further forgetting. If I do not ask the question of the foundation of philosophical thinking, philosophy turns into a set of mental practices - useful and practically effective (methodology of science, social system, ethical maxima, logical formalization of language ...), devoid of internal unity, which gives the mental activity of the general body. And in the context of such a loss of unity, we affirm that all these practices are transformed into mechanical tools, inverted and alien from thought, unrelated to what brought them to life - the real integrity of human existence in the world. The danger of such alienation is a topic for the individual text.

Of course, the assertion that the possibility of building and method called connection between the ancient beginnings of philosophical thought and philosophical thinking generally denied in modern philosophy fully and completely - not true and is not the purpose of this study. Feeling the need to establish the essential, existential-called bonds between various historical and philosophical formations leaves no modern philosophy, existing as leitmotively and fully articulated. It is impossible to ignore the fundamental Heidegger attempts to meticulously listen to ancient thinkers expressed (without falling into extremes inherent in contemporary philosophy of language) and simultaneously maintain existential path, which is expressed to have turned - in fact, these efforts are an excellent basis for said analytical methodology, and for finding a base called' communication historical and philosophical narratives of some universal unit, which is specific objectivity philosophical thinking.

\footnotetext{
${ }^{14}$ Бибихин В. Собственность. Философия своего. СПБ, Наука, 2012. 536 с. С. 15.
} 
Not to mention the intelligence of V.L. Petrushenko about the philosophy of Parmenides, Heraclitus, Pythagoras, Socrates, Sophists and Milesians in his book "Job or about man's self-stand" where the author brilliantly demonstrates that the achievement of ancient philosophy not only in introducing new topics for reflection, but a qualitative change ways of deployment Thinking at the Extreme Level: "Philosophy started from the 'beginning', but what was the beginning of philosophical thought? Again, perhaps no philosophy other than antiquity gives us the ability to see it all almost visibly"15.

The following statement by A. Akhutin also deserves attention and careful consideration: "There is no sense in comparing philosophical concepts, ideas, concepts, bypassing the decisive one: the very mind in which and in what these concepts are able to understand. Philosophies are not complete systems of concepts but sources of thought, minds that can still think. Starting a conversation about the transcendental ideas, Kant recalls Plato's ideas, but the ideas of Kant, the problem of making sense of 'pure reason' Kant and ideas, views Plato in his nous' and. To move from one to another, one has to do the difficult job of transforming mind, a kind of metanoia. Actually, philosophy is the taking into ownership - under its own responsibility - on all things, the world"16.

There is an implicit and essentially direct rationale for the study's stated necessity to appeal to the ontological, existential beginnings of ancient philosophy: in spite of individuality, complete historical contextuality and ideological affiliation of different historical and philosophical narratives, there is always a way to think, system, thought, one narrative into another. The abandonment of the optics of the pervasive vision of the history of philosophy as a generic property of modern and contemporary humanity (the history of philosophy as a meta-narrative, whose "landscape designer" should be a historical and philosophical methodology that does not avoid universalising definitions), and as a consequence of the distinction, the ontological beginnings of ancient (and any) philosophy are closed this way.

In modern philosophy (both in domestic and foreign, in particular American and analytical), a marked tendency to descriptive and instrumental study of ancient philosophy, which contains the risk of losing the ability to identify universal, parametric characteristics and boundary contours of thinking. This tendency leads to the formalization and alienation of the

${ }^{15}$ Петрушенко В. Л. Иов или о человеческом самостоянии. Львов, ПП «Новий світ2000», 2008. 339 c. C. 119.

16 Ахутин А. В. Философское существо европейской культуры. Памяти Владимира Бибихина. URL: http://bogoslov-club.org.ua/?p=5205 
question of the beginnings of ancient philosophy, and, as a consequence, to the formalization and alienation of philosophy in general. The question of the ontological beginnings of ancient philosophy is a challenge that has yet to be fulfilled. Its necessity is due to the fact that it is the only way of forming an adequate transcendental distance, through which thinking in its essential dimensions and everyday characteristics emerges as a specific subject of philosophical analysis.

\section{Methodological perspectives of the question of ontological principles of ancient philosophy}

Therefore, ancient philosophy is an intellectual formation that, despite its enormous influence, remains methodologically difficult to study. In the previous paragraphs, we have outlined the existing ways of appealing to antiquity in modern philosophy. Here, however, it is necessary to distinguish between the references existing within the local philosophical disciplines (ethics, social philosophy, political science, logic, epistemology) and those references that aim at ancient philosophy itself - those which are inherently historical and philosophical. The problem is that we have studied the methodological complexity generated by the complexity of a different order: there is no single answer to the question whether the history of philosophy only to state some ideas and called' bandages or she is entitled to the formulation universalizing judgments. And that is why there is a disorientation about the expected goals and results of modern antiquity. Clearly, addressing within individual subjects may have only instrumental character (for example, exploring the ethics of the Stoics, we aim not studying Stoic philosophy and solution' Liabilities certain problems within ethics as a science). And in that case, the partiality and utilitarian nature of our treatment is entirely justified and I do not carry any methodological risks. The problem begins when we expect practical and utilitarianly measured results from a specific historical and philosophical study, such as those we have with local disciplinary treatment. In our view, such an expectation is wrong. However, current methodological approaches to the study of local historical and philosophical traditions as unique narratives, which should not be interpreted by us as an element of some "universal" history of thought (among which the analytical approach described in the first paragraph), act to animate this kind of expectation, since in both cases (utilitarian recourse to antiquity and methodology of studying antiquity as a unique narrative) we are working on the subject of research from the standpoint of partiality. This leads to the opposite effect: first we dissociate from universalizing methodologies like Hegel's history of philosophy, arguing that it is some external "Nav' binding" problems, and then - carry the same "Nav' binding" search for a certain 
"constructive" or a proposal to formalize the movement of thought of ancient philosophers in the language of modern logic.

However, it is obvious that the search for the optimal method of any study aims at the closest possible approach to the subject of study. This is true of all forms of appeal to ancient philosophy described by us. However, in the second paragraph we prove that there is no absolutely effective method of conducting historical and philosophical research, since we are always in a different philosophical and intellectual context than the ideas and paradigms we are exploring. In general, this problematic nature is inherent in any philosophical thinking and any form of communication: our a priori location is a priori single and partial; human dimension of our measure of all things so head' related to our unique subjectiveness that in a sense we do not capable of absolute metaposition in relation to something that is beyond our vision. The problem in the very nature of the phenomenon: thinking, including philosophical, never thinks at the absolute level, because he thinks of himself by his own means and capabilities. Reflect the Beginning of Ancient Philosophy - would mean to reflect the thought as such in all its integrity and granularity. And so in the historical and philosophical research, we are always in conflict between pure spontaneity researched text (in the broad sense) and mediating power of grounding the text contextual definitions - which seemed to be «veiled look» reject researcher from the desired clarity. Different attempts to deal with this contradiction give rise to a variety of historical and philosophical approaches and methods. However, stealth beginnings of ancient philosophical thought as if it demonstrates their impotence or insufficient ness. The main pathos of historical and philosophical methodology is to find some ideal way of working with the thought expressed in the text beyond its contextual certainty.

However, this problematic moment is at the same time the beginning of philosophical thinking itself, and therefore it must be the beginning of the formation of any historical and philosophical methodology, in particular if we are talking about ancient philosophy.

Metaphysical questioning, certainly inherent philosophy, methodology search turned into universalizing opinions on interdependence' bonds and impacts of various traditions, which leads us to the realization of the necessity of the question of basic, ontological principles of these traditions (in this case - the ancient philosophy, and as a result - philosophy in general).

The question of the ontological beginnings of ancient thought is, in fact, a methodological bridge, which we lay down to the subject of study. Yes, we do not have the opportunity to reconstruct the authentic context of the origin of the first philosophy, we do not have the opportunity to put into the linguistic parameters of ancient Greek those contextual meanings that were embedded 
in that language by Plato, Thales or Heraclitus. Moreover, we are unable to immerse ourselves in a cosmocentric worldview setting as our own - again, because of our existential and historical location.

That is why we need such a context that would become common to us as researchers and representatives of ancient philosophy. In this context, the question is asked about the basic, first parameters of thinking in general, since this question is invariably relevant and relevant to both present and ancient times. If we accept modernity as a consequence of a certain historical development, and if we accept Western civilization as the beginning of which is rooted in the ancient Greek world, then the question of how ancient philosophy begins, from purely academic to practical, since it is a matter of community the beginnings and goals of philosophical thinking.

We have already noted that the question of "how ancient philosophy begins" is not a question of its preconditions or of actual events. Rather, it is a question of what is expected of philosophical reflection or of what it seeks. At some point, the human mind feels the need to find a qualitatively new basis for its own activity, a basis that does not boil down to utilitarian issues or a mythological-religious outlook. In this sense, the materialistic-object orientation of the ancient philosophical tradition gives it uniqueness and novelty: Ancient Greek thought seeks to work directly with the things themselves, and work at the level of their understanding, not merely creation or consumption. No matter what worldviews there are in mythology about the beginning of the world and its parameters of existence; it is important as it really is, in truth. This is what distinguishes the first philosophical insights inherent in Thales and the Pre-Socratics in general, from ancient Greek mythology, which was, of course, very philosophical, but, like any mythology, unjustified and unreflective. The search for some true order of things radically alters the vision of the world - first of all, ascertaining the existence of some true order of things. If there is a true order of things (which we grasp through natural-philosophical principles, atomistic cosmology, the distinction between being and nothingness), then obviously there is also some true order of understanding these things, simpler - what is called "right thinking". If there is some "right", true thinking - there is a certain possibility of knowing its laws and practicing it further. In other words, it is important not just to fix the source and the prerequisites of ancient philosophy, we must find out that it was the subject of the search.

Of course, the contextuality of the emergence of a particular historical and philosophical tradition enables us to comprehend the uniqueness and authenticity of this tradition, but the content of philosophical thought is thus not grasped. However, it does not embark on the path of total reduction of any context in the historical-philosophical formation, since in the context of 
displacement of historical, social, cultural and other contexts, we enter into our own context, which is often not so much research as utilitarian. In our opinion, the deep, existential basis for the content of certain ideas of a particular historical and philosophical tradition may be more accessible when we perceive the existence of these ideas as an element of the everyday human view of the world. In this case, everyday life should be understood not as a set of partial states, actions, activities and contexts, but as the totality of human existence in the world, as a certain ontological basis that is common to both the researcher and the subject of research. So we did not impose own ideological or utilitarian reasons certain philosophical traditions, does not use their instrumental way - we rather leads of itself, its own ontological context in line with the subject of study. This cannot be achieved by formalizing the ideas of a particular tradition or literalising them. Here, there is no need for freedom of interpretation or what should be called thinking in a certain dialogical community with the ideas of ancient philosophy, which is more inherent in continental philosophy, which accepts its own historicity as a meaningful rather than a formal moment.

The question arises: to what extent is further problematization of the question of the beginnings of ancient philosophy productive? The fact that one of its most unique features is its historical primacy. Any further historical and philosophical formations are formed through the acquisition and removal of previous intellectual traditions, neither of which can begin to "think for the first time". Even when we try to abandon our previous achievements by overcoming them critically (the crisis of classical rationality, non-classical philosophy), or when we try to revise the previous philosophical tradition from certain qualitatively new methodological foundations, we still find ourselves in a situation of correlation with this experience. Any attempt to "think for the first time" in today's world will take place in a world where certain intellectual events have already taken place. In this sense, the history of philosophy, read literally, or, conversely, overly generalized, can indeed become a burden that hinders the exercise of thought rather than substantiates it.

But ancient philosophy does not know "history of philosophy" as a selfcontained philosophical discipline, whether it be heading or genre. The main source from which the philosophical revelations of antiquity originate is not the texts of its predecessors, but the world in its immediate given. It is quite indicative that Aristotle's attempt to carry out the first historical and philosophical analysis of the preliminary unfolding of thought marks the end of an era of high classics of ancient philosophy. This is by no means a form of evaluative comparison of the forms of exercise of philosophy; Obviously, we are aware that it is a matter of qualitative change, not of "decline" or 
"degradation" of philosophical thinking. The desire of Aristotle (and generally all subsequent historical interconnective deployment of philosophical thinking) that the general context of existential philosophical origin requested and systematic responses to them adds another mode that context, philosophical refinement of previous eras.

This is the productivity of our appeal to the ontological beginnings of ancient philosophy: on the path that unfolds such an appeal (or inquiry) to us, we find a meaningful history of the emergence of philosophical thought from the immediacy of human existence in the world. Philosophical thinking is a unique and self-sufficient form of intellectual activity precisely because of its ability to reflect reflexively all possible contexts, without losing the ability to critically process them. In ancient philosophy we can find in the most pure form of this business situation "thinking first", which recognizes the need is intellectually-logical (and not, for example, religious and mythological) justification for each synthesis, metaphysical statements about the world and human forms of interdependence' connection. If we make an appeal to the ontological principles of ancient philosophy as a historical and philosophical methodology, we do not simply state the fact of certain ideas or explore forms and logical argumentation called' bonds within individual texts. We can fix this case, the logical necessity of occurrence of certain ideas, categories, topics and paradigms in particular their consistency. We can comprehend the situation of the emergence of philosophical thinking and thereby qualitatively improve any modern philosophy that we can call our own.

\section{CONCLUSIONS}

In modern philosophical practices, there is a marked tendency towards methodological and, quite often, metaphysical instrumentalism and utilitarianism. In the event that the settings get into the historical and philosophical methodology, risk reduction as a unique content specific historical and philosophical formation and leveling the issue of interdependence' bandages, influences and ideas of kinship structure to previous and successive paradigms. This, from a strategic perspective, significantly reduces and formalizes our understanding of the ontological causes and purpose of philosophical thinking in general. In this case, we begin to expect from the philosophy of specific and unambiguous methods, formulations, algorithms of change of reality (the same as what we expect from other local sciences) - instead of focusing on improving the quality of our understanding of the world at the level of its structural-systemic and holistic-universal measurements.

In this article, we have demonstrated that, in the case of contemporary references to ancient philosophy, there is an inclination to the above 
approaches, which leads to the loss of the possibility of understanding ancient philosophy as the beginning of philosophical thinking in general. Instead, we propose to update the question of the ontological beginnings of ancient philosophy as a methodological approach to its study. This enables us to connect context of a researcher and research subject from the position of the boundary common to modernity and antiquity, no nav' binding more local contexts and should mediated tissue of authentic historical and philosophical landscape. It also protects and resuscitates a metanarrative approach to the history of philosophy inherent in "continental" philosophy: by articulating the question of the ontological beginnings of ancient philosophy, we are able to make a cross-motion of the unfolding of thought, which takes place in the history of philosophical philosophy.

However, this issue needs further elaboration, and we conclude that, despite its ancient nature and high level of research, ancient philosophy still remains a methodological problem.

\section{SUMMARY}

The article is devoted to the review of present-day methodological approaches to ancient philosophy and demonstration of problems and shortcomings in them. Attention is drawn to the fact that in the search for a direct, non- contextual methodological approach, we very often lose sight of the historical-philosophical authenticity and integration of the formation under study in the general historical-philosophical process. The rejection of universalist tendencies in understanding the history of philosophy and the instrumentalization and utilization of approaches to the historicalphilosophical formation are subjected to critical consideration. It is proposed to update the question of the ontological principles of ancient philosophy as a methodological approach, which enables us to interconnect the contexts of the modern existence, we as researchers from the context of the existence of ancient philosophy. This is achieved by paying attention to the marginal dimensions of the existence of philosophical thinking in general, within which modernity and ancient philosophy coincide, since in the case of ancient philosophy we are dealing with the beginning of philosophical thinking in general.

\section{REFERENCES}

1. Annas Julia E. Hellenistic Philosophy of Mind. Berkeley: University of California Press, 1992. 246 p.

2. Hadot P. What is ancient philosophy? Cambridge, Mass. : Belknap Press of Harvard University Press, 2002. 
3. Ludwig Wittgenstein. Tractatus Logico-Philosophicus. URL: http://writing.upenn.edu/library/Wittgenstein-Tractatus.pdf.

4. Аристотель і аристотелізм: 2400 років по тому. Круглий стіл «Філософської думки». Ахутін А., Баумейстер А., Білий О., Васильченко А., Гомілко О., Жулай В., Звіядковський В., Козловський В., Попович М., Пролеєв С., Терлецький В., Туренко В., Хома О. Філософська думка : Наук. вісн. 2016. № 5. С. 6-26. URL: http://journal.philosophy.ua/issue/ 2016-no5.

5. Ахутин А. В. Европа - форум мира. К., Дух і літера, 2015. 88 с.

6. Ахутин А. В. Философское существо европейской культуры. Памяти Владимира Бибихина. URL: http://bogoslov-club.org.ua/?p=5205

7. Бибихин В. Собственность. Философия своего. СПБ, Наука, 2012. $536 \mathrm{c}$.

8. Вольф М., Бутаков П., Берестов И. Аналитическая история античной философии. Sententiae: Наук. вісн. 2013, № 1 (XXVIII). С. 96-108.

9. Греческая философия, Том 1. Антология. М. Канто-Спербер, Дж. Барнс, Л. Бриссон, Ж. Брюнсвиг, Г. Властос. Пер. с англ. М., 2006, «Греко-латинский кабинет» Ю. А. Шичалина. 520 с.

10. Лосев А.Ф. Дерзание духа. М., Издательство политической литературы, 1989. 366 с.

11. Навроцький В. «Топіка» Аристотеля і практичний поворот у сучасній логіці. Філософська думка: Наук. вісн. 2016. № 5. С. 27-32. URL: http://journal.philosophy.ua/issue/2016-no5.

12. Панич О. Аристотелева «усія»: між субстанцією, сутністю i неперекладністю. Філософська думка: Наук. вісн. 2016. № 5. С. 33-49. URL: http://journal.philosophy.ua/issue/2016-no5.

13. Петрушенко В. Л. Иов или о человеческом самостоянии. Львов, ПП «Новий світ-2000», 2008. 339 с.

14. Стан і перспективи українського антикознавства. Круглий стіл «Філософської думки». Баумейстер А., Вестель Ю., Звонська Л., Панич О., Пролеєв С., Чорноморець Ю., Секундант С. Філософська думка: Наук. вісн. 2012. № 1. C. 5-25. URL: http://journal.philosophy.ua/issue/ 2012-no51.

\section{Information about the author:} Vozniak S. V.,

Candidate of Sciences (Philosophy), Associate Professor at the Department of Philosophy, Sociology and Religious Studies, Faculty of Philosophy, Vasyl Stefanyk Precarpathian National University 57, V. Chornovola str., Ivano-Frankivsk, 76015, Ukraine 